\title{
Incarcerated Stomach in a Parastomal Hernia
}

\author{
Abdelwahed Ahmed, Sochorova Dana, El-Hakim Hisham, Hassan Malek, Zach Rudolf \\ Queen Elizabeth Hospital, King's Lynn, United Kingdom of Great Britain and Northern Ireland
}

Correspondence to: Dr. Ahmed Abdelwahed; email: drhamadaa@icloud.com

\begin{abstract}
Summary
Parastomal hernia is a rare cause of upper gastrointestinal bleeding. We present a case of an 82-year-old lady who presented with a one-month history of abdominal pain associated with coffee ground vomiting and intermittent melena. Gastroscopy showed bleeding from pyloric canal without a definite lesion. Abdominal CT showed herniation of the pre-pyloric and pyloric regions of the stomach into the hernial sac. She underwent a laparoscopic repair with extensive adhesiolysis, reduction of stomach, approximation of defect and placement of a mesh. She made excellent recovery and had no postoperative complications.
\end{abstract}

\section{Introduction}

Despite recent advances in surgical techniques, incidence of parastomal hernia and associated complications is increasing (1). Of particular concern are cases where the stomach or surrounding structures are involved, as these cases often present with a vague clinical picture that mimics gastric ulceration or obstruction, leading to delays in diagnosis and management. Upper gastrointestinal bleeding as a result of gastric parastomal hernia remains an uncommon and poorly characterized complication of ostomy procedures. To date, there has been little agreement on what is the best line of management for patients presenting with parastomal hernia with gastric involvement. We present a case of an 82-year-old lady who presented with a one-month history of abdominal pain associated with coffee ground vomiting and intermittent melena, and was found to have parastomal hernia containing pre-pyloric and pyloric regions of the stomach. She was managed successfully with surgical reduction and repair. Given the rarity and the clinical need, we present a comprehensive review of case reports of parastomal hernia containing stomach and associated complication.

\section{Case presentation}

An 82-year-old lady presented with a one-month history of abdominal pain, coffee ground vomiting and
Keywords: Parastomal hernia, Stomach

Ann Afr Surg. 2020; 17(3):132-133

DOI: http://dx.doi.org/10.4314/aas.v17i3.10

Conflicts of Interest: None

Funding: None

(C) 2020 Author. This work is licensed under the Creative Commons Attribution 4.0 International License.

Submitted: 24 July 2019

Revised: 4 December 2019

Accepted: 28 January 2020

Online first: 29 May 2020

intermittent melena. She had had a pan-proctocolectomy and terminal ileostomy at the age of 18 for ulcerative colitis. Her past medical history was significant for deep venous thrombosis for which she was on warfarin therapy. On examination her abdomen was soft, nontender and her stoma was functioning. An abdominal contrast-enhanced computed tomography of abdomen and pelvis scan showed a complicated parastomal hernia comprising the pre-pyloric and pyloric regions of the stomach with displacement of the first part of the duodenum (Fig. 1). She underwent an esophago-gastroduodenoscopy and was found to have active bleeding from pyloric canal, though no definite ulcer was found. Despite maximum conservative management, her symptoms increased and the patient wished to undergo surgical repair.

Laparoscopic exploration revealed a large incarcerated parastomal hernia with the omentum and antrum of the stomach (Fig. 2). The stomach looked bruised though it was viable. The stomach was reduced, the hernia sac was almost completely resected, and the defect was repaired with suturing and mesh placement (Fig. 3). Her postoperative period was uneventful. She has now been on our follow-up for the last 12 months with no recurrence of her symptoms. 
INCARCERATED STOMACH IN A PARASTOMAL HERNIA
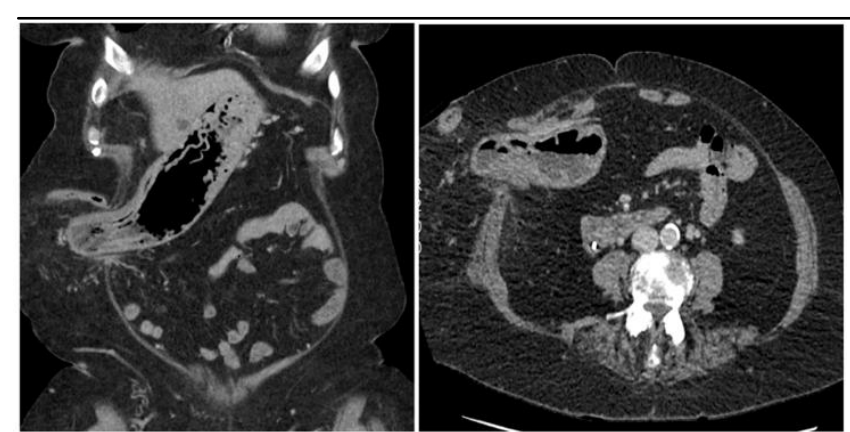

Figure 1. CT abdomen and pelvis showing stomach in the parastomal hernia
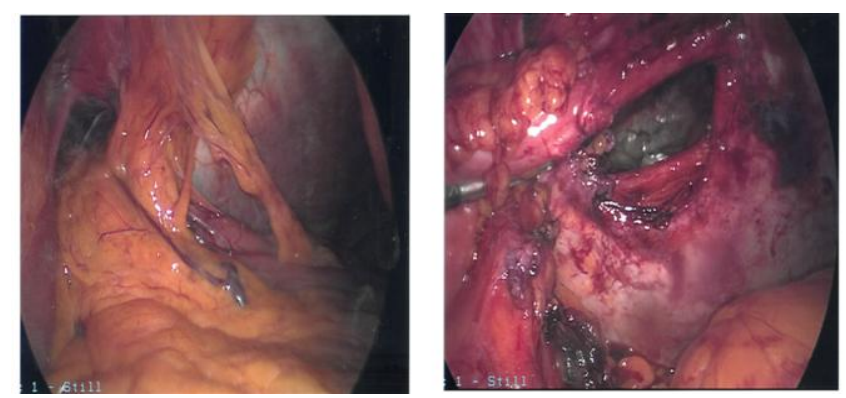

Figure 2. The defect containing stomach (left) and after reduction of contents (right)
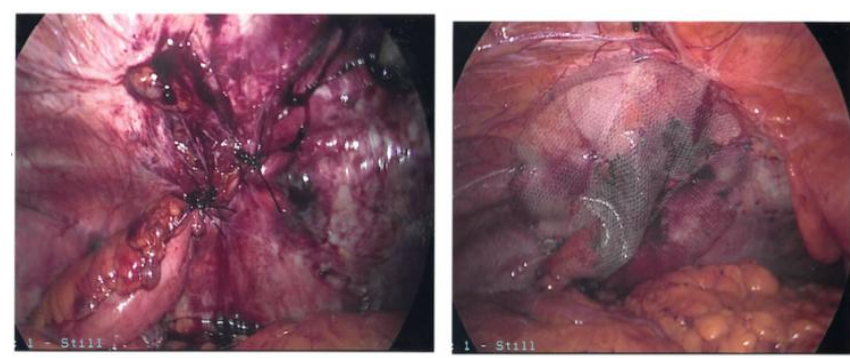

Figure 3. Repair of the defect with sutures (left) then mesh (right)

\section{Discussion}

We report this case of parastomal hernia complicated by upper gastrointestinal bleeding in an elderly lady. Despite her fragility and significant comorbidities, she underwent a laparoscopic repair and made excellent recovery. Right iliac parastomal hernia containing stomach remains uncommon. To our knowledge, nine previous cases have described parastomal hernia with gastric involvement (Table 1). Gastric outlet obstruction was the presenting complaint in most of the reported cases of gastric involvement in parastomal hernia. The underlying mechanism behind gastric herniation into parastomal space remains unclear. While the stomach lies in a relatively fixed anatomical position, previous reports have suggested that in a proportion of women of advanced age and history of multiple pregnancies the stomach might migrate from its native position (11).
Table 1. Previous published cases

\begin{tabular}{|c|c|c|c|c|}
\hline Reference & Age & Sex & $\begin{array}{l}\text { Presenting } \\
\text { complaint }\end{array}$ & Management \\
\hline $\begin{array}{l}\text { Waheed et } \\
\text { al. (2) }\end{array}$ & 58 & Female & $\begin{array}{l}\text { nausea, } \\
\text { malaise, } \\
\text { abdominal pain }\end{array}$ & Conservative \\
\hline $\begin{array}{l}\text { Barber-Millet } \\
\text { et al. (3) }\end{array}$ & 69 & Female & $\begin{array}{l}\text { vomiting, } \\
\text { abdominal pain }\end{array}$ & Surgical \\
\hline $\begin{array}{l}\text { Marsh et al. } \\
\text { (4) }\end{array}$ & 81 & Male & $\begin{array}{l}\text { vomiting, } \\
\text { abdominal pain, } \\
\text { distention }\end{array}$ & Surgical \\
\hline $\begin{array}{l}\text { Ramia-Angel } \\
\text { et al. (5) }\end{array}$ & 64 & Female & $\begin{array}{l}\text { abdominal pain, } \\
\text { vomiting }\end{array}$ & Conservative \\
\hline $\begin{array}{l}\text { Bota et al. } \\
(6)\end{array}$ & 41 & Female & $\begin{array}{l}\text { vomiting, upper } \\
\text { abdominal pain, } \\
\text { weight loss }\end{array}$ & Surgical \\
\hline $\begin{array}{l}\text { Ilyas et al. } \\
\text { (7) }\end{array}$ & 93 & Female & $\begin{array}{l}\text { vomiting, } \\
\text { abdominal } \\
\text { distention }\end{array}$ & Surgical \\
\hline Bull et al. (8) & 85 & Female & $\begin{array}{l}\text { abdominal pain, } \\
\text { vomiting }\end{array}$ & Surgical \\
\hline $\begin{array}{l}\text { Centauri et } \\
\text { al. (9) }\end{array}$ & 83 & Female & vomiting & Conservative \\
\hline $\begin{array}{l}\text { De Andrade } \\
\text { et al. (10) }\end{array}$ & 69 & Female & $\begin{array}{l}\text { abdominal pain, } \\
\text { bilious vomiting, } \\
\text { non-functioning } \\
\text { stoma }\end{array}$ & Surgical \\
\hline
\end{tabular}

\section{References}

1. Sohn YJ, Moon SM, Shin US, et al. Incidence and risk factors of parastomal hernia. J Korean Soc Coloproctol. 2012;28(5):241-246.

2. Waheed A, Zeller PE, Bishop PJ, et al. Gastric parastomal hernia: A case report of a rare yet fascinating clinical entity. Cureus. 2019;11(6):e4886.

3. Barber-Millet S, Pous S, Navarro V, et al. Parastomal hernia containing stomach. Int Surg. 2014;99(4):404-406.

4. Marsh AK, Hoejgaard M. Incarcerated and perforated stomach found in parastomal hernia: A case of a stomach in a parastomal hernia and subsequent strangulation-induced necrosis and perforation. J Surg Case Rep. 2013;2013(4).

5. Ramia-Angel JM, De la Plaza R, Quinones-Sampedro J, et al. Education and imaging. Gastrointestinal: Gastric incarceration in parastomal hernia. J Gastroenterol Hepato. 2012;27(8):1405.

6. Bota E, Shaikh I, Fernandes R, et al. Stomach in a parastomal hernia: Uncommon presentation. BMJ Case Reports. 2012;2012.

7. Ilyas C, Young AL, Lewis M, et al. Parastomal hernia causing gastric emphysema. Ann R Coll Surg Engl. 2012;94(2):e72-73.

8. Bull N, Chan DL, Ravindran P, et al. Gastric outlet obstruction secondary to parastomal hernia: case report and literature review. ANZ J Surg. 2019;89(3): e96-e97.

9. Centauri S, Buxey K, Chouhan H, et al. Beware the fully reducible large parastomal hernia in elderly female patients: acute gastric outlet obstruction in parastomal hernia. ANZ J Surg. 2020;90(4):e73-e74.

10. De Andrade VA, Coy CSR, Fagundes JJ, et al. Paraestomal hernia with gastric outlet obstruction: a case report and literature review. J Surg Case Rep. 2018(7): rjy177.

11. Ellingson TL, Maki JH, Kozarek RA, et al. An incarcerated peristomal gastric hernia causing gastric outlet obstruction. J. Clin. Gastroenterol. 1993;17(4):314-316. 